\title{
СМЕРТНОСТЬ ОТ ДОРОЖНО-ТРАНСПОРТНЫХ ПРОИСШЕСТВИЙ В РОССИИ: ПОДХОДЫ К ОЦЕНКЕ, ТЕНДЕНЦИИ И ПЕРСПЕКТИВЫ
}

\author{
АНАСТАСИЯ ПЬЯНКОВА, ТИМУР ФАТТАХОВ
}

\begin{abstract}
В России в 2016 г. общий коэффициент смертности от ДТП по данным полиции впервые снизился до уровня, не наблюдавшегося с 1971 г., после чего продолжил снижаться. Позитивные тенденции, видимо, послужили основой для оптимистичных иелей, заложенных в стратегии безопасности дорожного движения на 2018-2024 г2. (стратегия БДД).

Опираясь на данные полищии, государственную статистику смертности, международные базы данных о смертности и безопасности дорожного движения, авторы пытаются ответить на вопросы: достижимы ли поставленные цели в указанные сроки, насколько они согласуются с европейскими тенденциями дорожно-транспортной смертности, а также с существующей в России пространственной, возрастной и категориальной дифференциицией дорожнотранспортной смертности.
\end{abstract}

Исследование показало, что установленные сроки достижения целевых ориентиров в стратегии БДД очень сжаты. На сегодняшний день лишь в крупных и средних по численности населения городах есть потенциал для реализации стратегии, где общий коэффициент смертности к 2024 г. не должен превышать 1,5-2 погибших на 100 тыс. человек, тогда как в небольших городах и сельских населенных пунктах - 2,5-3 погибших на 100 тыс. человек. На протяжении долгих лет наибольшему риску смерти на российских дорогах подвержены водители и пассажиры в возрасте 15-44 года и пешеходы старше 60 лет, не нашедшие отражения в стратегии БДД в качестве приоритетных категорий.

Помимо этого, в статье показано, что для устранения существующих расхождений между опубликованными числами погибших двух официальных систем учета (полиции и Росстата) самымм первым иагом может быть отказ Росстата от используемого в данный момент подхода $\kappa$ выделению контингента погибших в ДТП на основе действующей краткой номенклатуры причин смерти и переход на один из двух международных вариантов агрегаџии трехзначных кодов причин смерти, используемый ВОЗ для выделения числа погибших в ДТП.

Ключевые слова: дорожно-транспортные происшествия, безопасность дорожного движения, дорожно-транспортная смертность, полиция, государственная статистика смертности.

\section{ВВЕДЕНИЕ}

В отличие от европейских стран, где с 1970-х годов наблюдается последовательное снижение смертности от дорожно-транспортных происшествий (ДТП), в России долговременная динамика дорожно-транспортной смертности имеет волнообразный характер. Но в последние годы в России сохраняется позитивная тенденция снижения дорожно-транспортной смертности, сложившаяся после 2004 г.

\footnotetext{
АНАСТАСИЯ ИвАНОВНА ПьяНКОВА (apyankova@hse.ru), НАЦИОНАЛЬНЫЙ ИССЛЕДОВАТЕЛЬСКИЙ УНИВЕРСИТЕТ «ВЫСШАЯ ШКОЛА ЭКОНОМИКИ», РОССИЯ.

ТИМУР АСФАНОВИЧ ФАТТАХОВ (tfattahov@hse.ru), НАЦИОНАЛЬНЫЙ ИССЛЕДОВАТЕЛЬСКИЙ УНИВЕРСИТЕТ «ВЫСШАЯ ШКОЛА ЭКОНОМИКИ», РОССИЯ.

ИССЛЕДОВАНИЕ ВЫПОЛНЕНО ПРИ ФИНАНСОВОЙ ПОДДЕРЖКЕ РФФИ В РАМКАХ НАУЧНОГО ПРОЕКТА №19-013-ООО6О «ДОРОЖНО-ТРАНСПОРТНАЯ СМЕРТНОСТЬ В РОССИИ И ЕЕ РЕГИОНАХ: АНАЛИЗ НА БАЗЕ СВЯЗАННЫХ ДАННЫХ ПОЛИЦИИ И СВИДЕТЕЛЬСТВ О СМЕРТИ» .
}

СТАТЬЯ ПОСТУПИЛА В РЕДАКЦИЮ В ИЮЛЕ 2019 Г. 
В 2016 г. общий коэффициент смертности (ОКС) от ДТП по данным полиции и стандартизированный коэффициент смертности, рассчитанный на основе государственной статистики смертности, до того испытывавшие колебания, достигли исторического минимума (13,9 и 12,6 погибших на 100 тыс. человек соответственно) после чего продолжили снижаться.

Тенденции последних лет, видимо, явились основой для оптимистичных целевых ориентиров, принятых в официальной стратегии безопасности дорожного движения (стратегия БДД) ${ }^{1}$ : снижения общего коэффициента смертности до 4 погибших на 100 тыс. человек к 2024 г. и стремления к нулевому уровню смертности к 2030 г.

Опираясь на данные двух государственных систем учета погибших в ДТП в России (полиции и Росстата), а также на международные базы данных о смертности и безопасности дорожного движения, авторы пытаются ответить на следующие вопросы: достижимы ли целевые ориентиры в предложенные сроки и если достижимы, то для каких регионов и категорий участников дорожного движения; насколько эти ориентиры согласуются с мировыми тенденциями снижения дорожно-транспортной смертности.

Однако прежде, чем ответить на эти вопросы, необходимо рассмотреть различные подходы к понятию погибшего в ДТП в двух разных системах учета погибших в России, его вариации внутри каждой из этих систем, соответствие этих подходов международным подходам к выделению категории лиц, погибших в ДТП, и, объяснить различия в оценках абсолютного числа погибших в ДТП в России.

\section{ПОНЯТИЕ ПОГИБШЕГО В ДТП В РАЗНЫХ СИСТЕМАХ УЧЕТА ПОГИБШИХ}

Из стратегии БДД следует, что показателем, оценивающим ее эффективность, является общий коэффициент смертности от ДТП, рассчитываемый по данным полиции ${ }^{2}$. В России, как и во многих странах мира, функционируют две официальные государственные системы учета погибших в ДТП: полиции и Росстата, ведущего учет естественного движения населения. Однако, если понятие погибшего в ДТП, используемое полицией, с момента ратификации Венской конвенции о дорожном движении 1968 г. существенно не менялось, то понятие умершего в ДТП в рамках государственной статистики смертности зависело от действующей номенклатуры причин смерти.

Международные классификации болезней и причин смерти (МКБ) никогда напрямую не применялись в СССР. Действующие в СССР краткие номенклатуры причин смерти были адаптированы к МКБ, но существенно отличались от нее. С 1965 по 1988 г. в СССР действовало 4 краткие номенклатуры причин смерти. Особенностью трёх из них (номенклатура-1965, номенклатура-1970, номенклатура-1981) было разделение внешних причин смерти, в том числе всех рубрик транспортных происшествий, на связанные и не связанные с производством (таблица П1 Приложения). Ситуация изменилась с

\footnotetext{
${ }^{1}$ Распоряжение Правительства РФ от 8 января 2018 г. №1-р «Стратегия безопасности дорожного движения в Российской Федерации на 2018-2024 годы».

2 Здесь и далее под полицией мы понимаем ГИБдД МВД РФ. 
пересмотром краткой номенклатуры 1988 г., действовавшей до 1998 г., где данное разделение было отменено и статистические таблицы формы №№5 и 56 с информацией о количестве смертей по полу, возрасту и причинам смерти заменила единая статистическая отчетная форма C-51 «Распределение умерших по полу, возрастным группам и причинам смерти» (Милле и др. 1996). В период действия последней версии советской номенклатуры 1988 г. транспортные происшествия делились на три категории: 1) несчастные случаи, связанные с мототранспортом; 2) автомототранспортный несчастный случай на общественной дороге в результате наезда на пешехода; 3) автомототранспортные несчастные случаи. Между тем в кратком листе причин смерти МКБ-9 было выделено пять групп транспортных происшествий: 1) происшествия с участием автомобильного транспорта (motor vehicle traffic accidents); 2) происшествия с другими с дорожными транспортными средствами; 3) железнодорожные происшествия; 4) аварии на водном транспорте; 5) авиационные и космические аварии.

После распада СССР агрегированная статистика смертности по причинам смерти с начала 1990-х годов стала передаваться во Всемирную организацию здравоохранения (BO3). В её информационных ресурсах, в европейской базе детализированных данных о смертности, содержатся данные по России о числе погибших в мототранспортных происшествиях (motor vehicle traffic accident ${ }^{3}$ ) с 1980 по 1998 г. Для этого периода аналогом данного понятия ВО3 считает погибших, учтенных в первых двух категориях транспортных происшествий из советской номенклатуры 1988 г. В период с 1988 по 1998 гг. число погибших в России в мототранспортных происшествиях, опубликованное в данной базе, и число погибших в ДТП по данным полиции не имеют существенных расхождений (голубая и синяя линии на рисунке 1 соответственно). Поэтому эти понятия можно считать синонимичными.

Ситуация изменилась с введением МКБ-10, где дифференциация транспортных причин смерти, связанных с наземными безрельсовыми видами транспорта, стала более подробной. В МКБ-9 к мототранспортным происшествиям относились все происшествия с участием мототранспортных средств. В МКБ-10 было введено разграничение категорий участников дорожного движения: пешеход, велосипедист, мотоциклист и лицо, находящееся в транспортном средстве, виды которого в отличие от МКБ-9 подробно дифференцированы. Вместо общего понятия «мототранспорта» использованы следующие виды наземного транспорта: велосипед, мотоцикл, трехколесное транспортное средство, легковая машина, пикап, грузовая машина, автобус и другие виды транспортных средств. Наиболее подробный (четвёртый) знак кода стал уточнять одновременно и категорию участника дорожного движения, находящегося на/в транспортном средстве (водитель, пассажир или человек, неуточненный как водитель или пассажир), и место происшествия (дорожное, недорожное или неуточненное как дорожное или недорожное происшествие). С целью сохранения сопоставимости временных рядов ВОЗ пришлось определить набор трехзначных кодов причин смерти МКБ-10, которые соответствовали бы понятию

\footnotetext{
3 Здесь и далее мы приводим названия причин смерти также и на английском языке. Нам кажется это важным, поскольку иногда русские названия не отражают сути или являются неточным переводом английского варианта.
} 
«умерший в мототранспортном происшествии (motor vehicle traffic accident)» из МКБ-9: V02-V04; V09; V12-V14; V20-V79; V82-V87; V894. Помимо этого, ВО3 в «Глобальных оценках здоровья» использует еще один, более широкий, вариант группировки транспортных дорожных кодов причин смерти для выделения числа лиц погибших в «дорожных происшествиях» (road injury): V01-V04; V06; V09-V80; V87; V89; V99 (World health organization 2018b: 69).

В России с переходом на МКБ-10 в 1999 г. была введена новая российская краткая номенклатура причин смерти, основанная на МКБ-10. С момента перехода действовало три версии российской краткой номенклатуры причин смерти (таблица П2 Приложения).

В номенклатуре 1999 г., действовавшей по 2005 г., вслед за МКБ-10 поменялся критерий группировки кодов и были выделены следующие три группы погибших в транспортных происшествиях: 1) пешеход, пострадавший в результате транспортного несчастного случая; 2) лицо, находившееся в легковом автомобиле, пострадавшее в результате транспортного несчастного случая; 3) другие и неуточненные транспортные несчастные случаи. Новое деление погибших в транспортных происшествиях не сопоставимо с предшествующим, соответственно на его основе невозможно выделить категорию погибших в мототранспортных происшествиях. Возможно, в этот период не ставилась задача определения числа лиц, погибших в ДТП, на основе статистики естественного движения населения, что косвенно отражается и в официальных публикациях Росстата. Например, в «Демографическом ежегоднике России» с 1999 г. по 2005 г. опубликовано только общее число погибших в транспортных происшествиях.

В 2006 г. российская краткая номенклатура причин смерти была пересмотрена, в результате чего каждая из предыдущих трех категорий погибших в транспортных происшествиях была разделена на погибших в дорожных и недорожных происшествиях. Сумму погибших только в дорожных происшествиях Росстат стал называть «умершие от дорожно-транспортных происшествий (motor road accidents (V01-V89)» и с 2006 г. публиковать в «Демографическом ежегоднике России». Число погибших в ДТП на основе статистики естественного движения населения (красная линия на рисунке 1), определенное таким образом, стало существенно ниже числа погибших в ДТП по данным полиции (в 2006 г. 22,1 тыс. человек против 32,7 тыс. соответственно).

Попытка преобразования рядов данных с целью их представления в соответствии с одной и той же краткой номенклатурой с помощью метода реконструкции была предпринята в международной базе данных о смертности по причинам смерти ${ }^{5}$. В ней данные по России о числе умерших по причинам смерти, в том числе по 6 рубрикам транспортных происшествий, за длительный период с 1956 по 2005 г. представлены в соответствии с российской краткой номенклатурой причин смерти, действовавшей с 2006 по 2010 г.

\footnotetext{
${ }^{4}$ https://gateway.euro.who.int/en/indicators/hfa_167-1740-sdr-motor-vehicle-traffic-accidents-all-ages-per-100000/visualizations/\#id=19098\&tab=notes (дата обращения: 13.09.2019).

${ }^{5}$ https://www.causesofdeath.org/cgi-bin/country.php?country=RUS (дата обращения: 13.09.2019). 
В 2011 г. российская краткая номенклатура причин смерти, действующая до сих пор, в очередной раз была пересмотрена и расширена. Как ранее уже отмечалось исследователями, «...для большинства групп причин номенклатура 2011 г. представляет собой лишь более детализированную номенклатуру 2006 г., исключение составляют транспортные происшествия, классификация которых стала не просто более детальной, но изменился сам принцип группировки кодов МКБ-10 по рубрикам российской номенклатуры...» (Данилова 2015). В первую очередь группировка стала происходить по третьему знаку кода: категории участника дорожного движения (пешеход; велосипедист, мотоциклист, лицо в трехколесном транспортном средстве; лицо, находившееся в автотранспортном средстве). Во вторую очередь - по четвертому знаку кода: месту происшествия (дорожное, недорожное, для пешеходов еще и неуточненное как дорожное или недорожное транспортное происшествие). В итоге вместо 6 групп транспортных причин смерти выделено 13 (таблица П2 Приложения). Сумму погибших по трем из них (1 - пешеход, получивший травму в результате дорожного транспортного происшествия (кроме травм на железной дороге); 2 - велосипедист (любой), мотоциклист (любой) и лицо, находящееся в трехколесном транспортном средстве, пострадавшие в результате дорожного транспортного случая; 3 - лицо, находившееся в автотранспортном средстве, пострадавшее в результате дорожного транспортного случая) Росстат продолжает называть в «Демографическом ежегоднике России» «умершие от дорожно-транспортных происшествий (motor road accidents (V01-V89)» (Федеральная служба... 2017). Этот подход подразумевает невключение как всех недорожных происшествий, так и погибших пешеходов с неуточненным местом происшествия. В итоге за тем же названием стоит иная группа кодов причин смерти ${ }^{6}$, не соответствующая ни группе кодов, используемой ВО3 для определения числа погибших в мототранспортных происшествиях, ни понятию погибшего в ДТП из краткой российской номенклатуры 2006 г. Видимо, по этой причине в европейской базе детализированных данных о смертности с 1999 г. по России публикуется только число погибших во всех видах транспортных происшествий.

Ситуация усугубляется тем, что на новый принцип группировки транспортных кодов накладывается особенность кодирования транспортных происшествий в медицинском свидетельстве о смерти судебно-медицинскими экспертами. Так, на примере г. Москвы было показано, что существует проблема определения места происшествия в случае, если погибший являлся пешеходом. Значительное число таких случаев относится к неуточненным как дорожное или недорожное происшествие (179 из 264 погибших пешеходов в Москве в 2016 г.) (Пьянкова и др. 2019). В результате они попадают в рубрику «пешеход, пострадавший в результате неуточненного транспортного случая (кроме железнодорожного)» и не относятся Росстатом к числу погибших в ДТП. Это обстоятельство в совокупности с новым принципом группировки транспортных кодов по рубрикам краткой номенклатуры и выделением на их основе контингента лиц, погибших в ДТП, приводит к занижению числа погибших в ДТП в России, которое публикуется в «Демографическом ежегоднике России» (Федеральная служба... 2017; красная линия на рисунке 1).

${ }^{6}$ V01-V04(1); V09(2-3); V10-V18, V20-V28(3-9); V19, V29-V39(4-9); V40-V79(4-9); V83-V86(2). 
В итоге долгосрочные тенденции дорожно-транспортной смертности в России проблематично исследовать, используя агрегированные рубрики краткой российской номенклатуры причин смерти. База данных по причинам смерти за период с 1965 по 2014 г. позволяет это выполнить только до 2014 г. и в соответствии с уже не действующей краткой номенклатурой 2006 г. К тому же на ее основе невозможно получить сопоставимую с международным понятием категорию лиц, погибших в ДТП. Тем не менее это можно сделать, используя индивидуальные неперсонифицированные данные об умерших в России и международные подходы к агрегации кодов причин смерти для выделения погибших в ДТП, о которых говорилось выше.

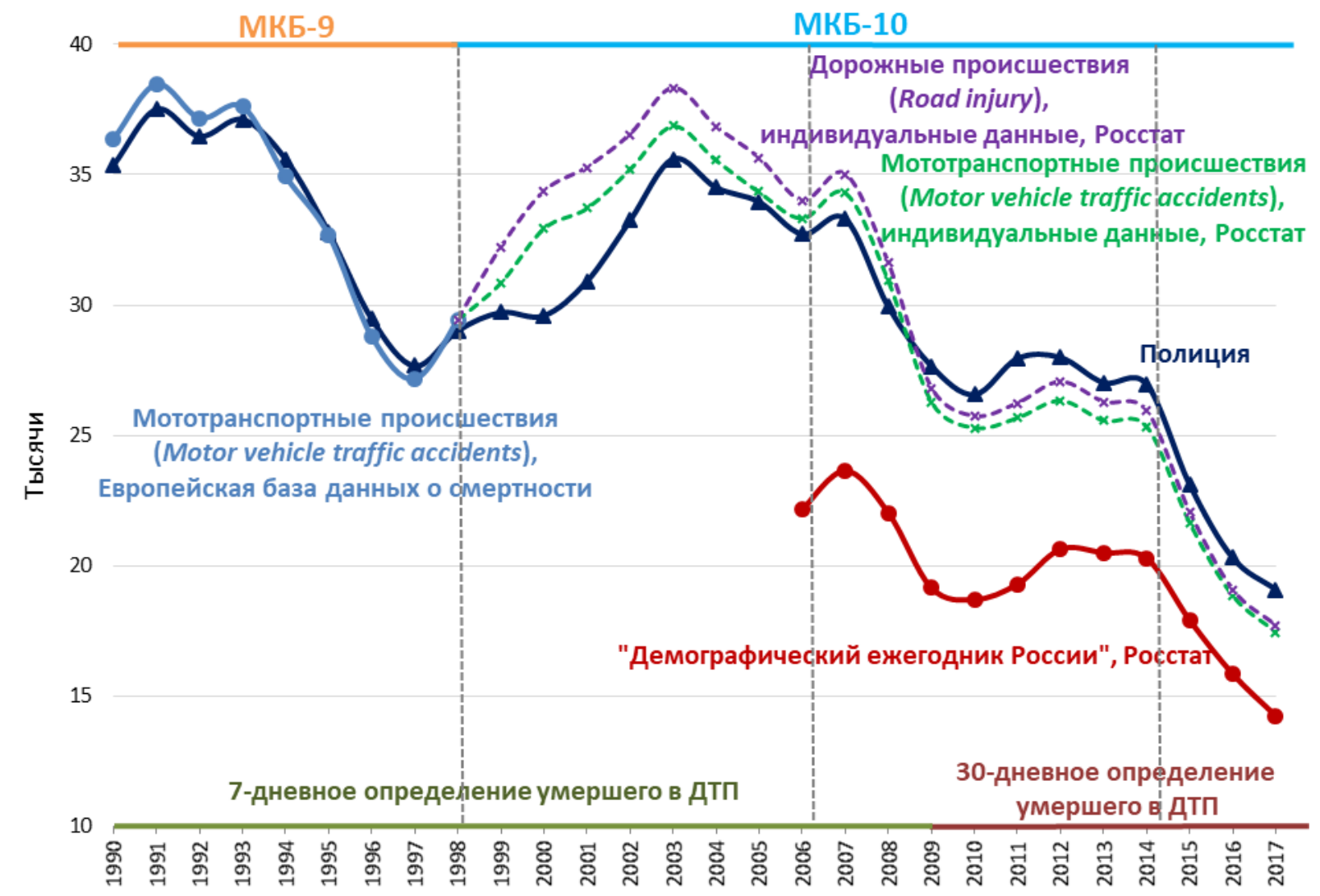

\section{Рисунок 1. Число погибших в ДТП в России по разным источникам информации, тыс. человек}

Источник: Данные полиции, «Демографический ежегодник России» (Федеральная служба... 2017), индивидуальные данные Росстата.

На рисунке 1 видно, что число погибших в «мототранспортных» и «дорожных» происшествиях с 1999 г., определённое на основе индивидуальных данных, хотя и расходится с числом погибших в ДТП по данным полиции, но существенно меньше, чем с числом умерших в ДТП по данным, публикуемым в «Демографическом ежегоднике России» (Федеральная служба... 2017). Максимальные расхождения, наблюдавшиеся в период перехода с МКБ-9 на МКБ-10, могут быть объяснены не только сменой классификаций, но и кардинальными изменениями в системе кодирования и сбора статистической информации о причинах смерти в России (Danilova el al. 2016). C 1999 по 2008 г. число погибших в «дорожных происшествиях», как и в «мототранспортных происшествиях» по данным статистики естественного движения населения, было выше 
числа погибших в ДТП по данным полиции. С 2009 г. оно стало ниже, что обусловлено переходом России и соответственно государственной системы учета полиции на 30 -дневное определение погибшего в ДТП, тогда как до этого использовалось 7-дневное определение.

В таблице 1 представлен спектр оценок числа погибших в дорожно-транспортных происшествиях в России в 2016 г., исходя из разных официальных источников информации и в зависимости от выбора подхода к агрегации подробных кодов причин смерти МКБ-10 в государственной статистике смертности.

Таблица 1. Число погибших в ДТП в России по разным источникам информации в 2016 г., человек

\begin{tabular}{|c|c|c|c|}
\hline \multirow[b]{2}{*}{ № } & \multirow[b]{2}{*}{ Государственные системы учета погибших в ДТП } & \multicolumn{2}{|c|}{ Число погибших в зависимости от } \\
\hline & & $\begin{array}{l}\text { года регистрации } \\
\text { смерти }\end{array}$ & $\begin{array}{c}\text { года } \\
\text { смерти }\end{array}$ \\
\hline 1 & Полиция & 20308 & Не применимо \\
\hline 1 (a) & $\begin{array}{l}\text { Полиция с поправкой на ДТП, произошедшие вне дорог общего } \\
\text { пользования }\end{array}$ & 19725 & Не применимо \\
\hline 2 & Статистика естественного движения населения, Росстат: & & \\
\hline 2.1 & Дорожные происшествия (road injury), индивидуальные данные: & & \\
\hline 2.1.1 & Трехзначные коды МКБ-10 & 19100 & 19186 \\
\hline 2.1.2 & Четырехзначные коды МКБ- $10^{7}$ & 17431 & 17437 \\
\hline 2.2 & $\begin{array}{l}\text { Мототранспортные происшествия } \\
\text { (motor vehicle traffic accidents), индивидуальные данные }\end{array}$ & 18969 & 18948 \\
\hline 2.3 & $\begin{array}{l}\text { Умершие от дорожно-транспортных происшествий (motor road } \\
\text { accidents (V01-V89), «Демографический ежегодник России») }\end{array}$ & 15800 & 15805 \\
\hline
\end{tabular}

Источник: Даннье полищии, «Демографический ежегодник России» (Федеральная служба... 2017), индивидуальные данные Pосстата.

По данным представителей научного центра безопасности дорожного движения МВД РФ, в официальное число погибших, учитываемых полицией, попадают случаи, не относящиеся к категории дорожно-транспортных происшествий в соответствии с определением этого понятия в «Глоссарии по статистике транспорта» (Европейская экономическая комиссия... 2009: 93). К таким событиям относятся случаи, произошедшие вне дорог (просека, лес, поле, лед замёрзшего водоёма; автостоянка, отделённая от проезжей части; многоэтажный паркинг; надземное или подземное сооружение и др.) или на закрытых территориях вне общего пользования (карьер, аэродром, пристань, производственная, технологическая, служебная, складская или иная хозяйственная территория, используемая для проезда по дамбе). В 2016 г. по данным полиции произошло 583 подобных происшествия (Баканов 2019). Без учета вышеописанных случаев число погибших в ДТП в 2016 г. составило бы 19,7 тыс. человек (таблица 1). Наибольшее приближение к данной оценке дает выборка трехзначных кодов причин смерти (V01-V04; V06; V09-V80; V87; V89; V99), относимых ВО3 к «дорожным» происшествиям, в которых в 2016 г. погибло 19,1 тыс. человек.

\footnotetext{
${ }^{7}$ V01-04.1-9;V06.1-9;V09.2-3;V10-14.3-9;V15-19.4-9;V20-28.3-9;V29-79.4-9;V80.3-5;V81.1;V82.1,8,9;
} V83-86.0-3;V87.0 9;V89.2,3,9;V99;Y85.0. 
Поскольку принципиальных противоречий о числе погибших в данных полиции и государственной статистики смертности не прослеживается, далее мы используем оба этих источника информации.

\section{СТРАТЕГИЯ БДД В КОНТЕКСТЕ ТЕНДЕНЦИЙ РОССИЙСКОЙ И ЕВРОПЕЙСКОЙ ДОРОЖНО-ТРАНСПОРТНОЙ СМЕРТНОСТИ}

За период реализации стратегии БДД общий коэффициент смертности должен снизиться в 3,5 раза и не должен превышать 4 погибших на 100 тыс. человек. В 2017 г. подобный и ниже уровень дорожно-транспортной смертности наблюдался в 13 странах: Великобритании, Германии, Дании, Израиле, Ирландии, Испании, Нидерландах, Норвегии, Финляндии, Швеции, Швейцарии, Эстонии, Японии (IRTAD 2018). В 1970-е годы в этих странах уровень смертности варьировался от 13 до 19 погибших на 100 тыс. человек, как и в России в последние годы. Только спустя 30 лет в этих странах уровень смертности снизился до 4-5 погибших на 100 тыс. человек.

В начале 2000-х годов под эгидой ООН и ВОЗ была сформулирована совершенно новая задача, вызов был брошен не очередной нозологической форме инфекционных заболеваний, а одной из внешних причин смерти - дорожно-транспортным происшествиям и их последствиям. В Глобальных целях устойчивого развития постулирована необходимость сократить смертность от ДТП вдвое к 2020 г. ${ }^{8}$. В Европе с 2011 г. стартовала вторая волна глобального плана «Десятилетие действий по обеспечению безопасности дорожного движения 2011-2020 гг.» ${ }^{9}$. Ее целью является снижение числа погибших от ДТП в Европейском Союзе (ЕС) в соответствии с глобальными целями устойчивого развития. В основе данного плана лежат принципы, заложенные в государственной шведской концепции в сфере безопасности дорожного движения «Видение ноль». Она была разработана в 1997 г., когда число погибших в ДТП в Швеции составляло 541 человек или 6 погибших на 100 тыс. человек. При таком уровне дорожно-транспортной смертности лозунг «нулевой смертности» от ДТП казался оправданным и достижимым. На первом этапе реализации концепции, была поставлена цель снизить число смертей на 50\% к 2007 г. относительно 1996 г. К концу ее реализации число погибших снизилось всего на 13\%. В 2017 г. после 20 лет реализации шведской программы общий коэффициент смертности от ДТП составил 2,7 погибших на 100 тыс. человек.

В России в рамках Федеральных целевых программ (ФЦП ${ }^{10}$ на 2006-2012 и на 2013-2020 гг. запланированное снижение абсолютного числа погибших в ДТП в целом соответствовало аналогичным планам снижения числа умерших в ДТП в других странах (IRTAD 2018). Так, в ФЦП на период 2006-2012 гг. предполагалось «сокращение количества лиц, погибших в результате ДТП, в 1,5 раза к 2012 году по сравнению с 2004

\footnotetext{
${ }^{8}$ https://sustainabledevelopment.un.org/sdg3 (дата обращения: 13.09.2019).

${ }^{9} \mathrm{https}: / /$ www.unece.org/fileadmin/DAM/trans/roadsafe/docs/A-RES-64-255r.pdf (дата обращения: 13.09.2019).

${ }^{10}$ В России в первой Федеральной целевой программе (ФЦП) на период 1996-1998 гг. ${ }^{10}$ снижение числа погибших в ДТП не являлось главной целью, а было одной из задач в рамках общей цели повышения безопасности дорожного движения. Не оговаривалось также, на сколько должно снизиться число погибших в ДТП.
} 
годом» ${ }^{11}$ или на 33\% к базовому году. В ФЦП на период 2013-2020 гг. планировалось «сокращение случаев смерти в результате дорожно-транспортных происшествий к 2020 году на 8 тыс. человек по сравнению с 2012 годом» ${ }^{12}$, или на $29 \%$ к базовому году.

Соотношение планового и реального числа погибших в ДТП в России и странах EC-28 показывает, что фактическое снижение смертности от ДТП в ЕС-28 почти никогда не достигало запланированных значений (рисунок 2). В России же фактическое снижение числа умерших в ДТП в основном было интенсивней запланированного, а целевые показатели ФЦП на 2013-2020 гг. были достигнуты существенно ранее запланированного срока.

Россия

60

50

40

30

20

10

0

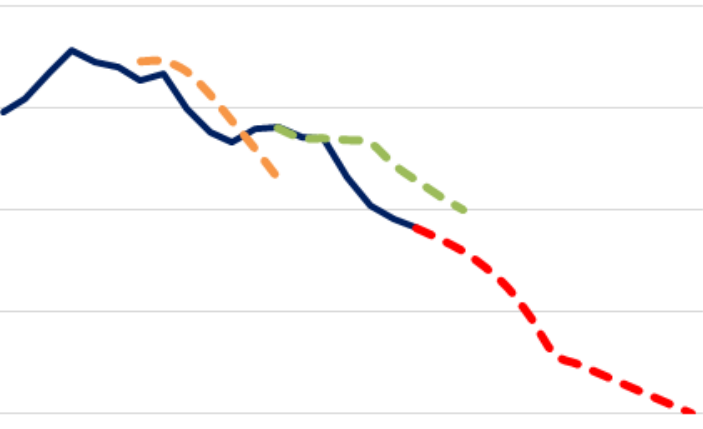

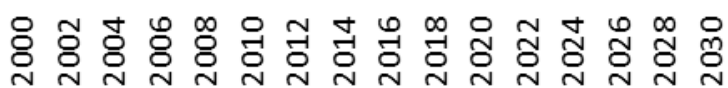

—— Факт (полиция)

- - - ФЦП 2006-2012

- - - ФЦП 2013-2020

- - - Стратегия БДД 2018-2024
EC-28

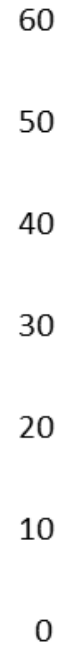

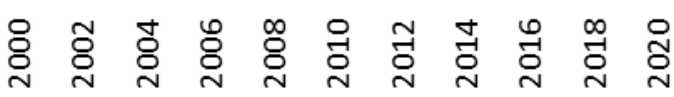

- ЕС Факт

- - - Задача 2000

- - - Задача 2010

Рисунок 2. Запланированное и фактическое число погибших в ДТП в России и ЕС-28, тыс. человек

Источник: Составлено по (European Coтmission 2017), данным полищии и ФЦП.

Стратегия БДД на 2018-2024 гг. - первый документ, где цель сформулирована в относительных показателях смертности (снижение числа умерших на 100 тыс. населения). Если пересчитать этот показатель в абсолютное число умерших, учитывая средний вариант прогноза численности населения Росстата до 2030 г., то получится, что абсолютное число погибших в ДТП должно снизиться на 68\% за 7 лет, т. е. снижение должно быть более чем

\footnotetext{
${ }^{11}$ Постановление Правительства РФ от 20 февраля 2006 г. №100 «О федеральной целевой программе «Повышение безопасности дорожного движения в 2006 - 2012 годах».

12 Постановление Правительства РФ от 3 октября 2013 г. №864 «О федеральной целевой программе «Повышение безопасности дорожного движения в 2013 - 2020 годах».
} 
в 2 раза интенсивней по сравнению с предыдущими программами. Подобные планы в меньшей степени согласуются с международной практикой, где планируемое снижение смертности никогда не превышало 50\% за 10 лет (IRTAD 2018). K тому же в EC-28, опираясь на концепцию «Видение ноль», полное предупреждение дорожно-транспортной смертности в качестве цели ставят лишь к 2050 г. (UN Road Safety... 2010).

Международный опыт показывает, что достигнуть столь низких показателей смертности от ДТП (4 погибших на 100 тыс.) в столь сжатые сроки (7 лет), еще никому не удавалось (таблица 2). Число лет, потребовавшееся для снижения ОКС с 13 до 4 погибших на 100 тыс. человек, варьировалось от 33 лет в Норвегии до 11 лет в Испании. Чем ниже уровень дорожно-транспортной смертности, тем больше времени требуется для его дальнейшего снижения, поскольку прежние меры БДД в новых условиях уже не приводят к столь интенсивному снижению. Для его обеспечения требуются новые меры и инструменты, предполагающие более сложные инфраструктурные, градостроительные решения и, что самое главное, изменение поведения людей.

В стратегии БДД цель снижения смертности от ДТП согласуется с международной повесткой, чего нельзя сказать о запланированных сроках ее достижения.

Таблица 2. Число лет, потребовавшееся для снижения ОКС от ДТП с 13 до 4 погибших на 100 тыс. человек в странах, где в 2017 г. ОКС был ниже 4 погибших на 100 тыс. человек

\begin{tabular}{|c|c|c|c|c|c|}
\hline № & Страна & $\begin{array}{c}\text { Год, когда } \\
\text { ОКС = } 13 \\
\text { погибших на } \\
100 \text { тыс. } \\
\text { человек } \\
\end{array}$ & $\begin{array}{c}\text { Год, когда } \\
\text { ОКС = 4 } \\
\text { погибших на } 100 \\
\text { тыс. человек }\end{array}$ & $\begin{array}{c}\text { Число лет, } \\
\text { потребовавшееся для } \\
\text { снижения ОКС с } 13 \text { до } 4 \\
\text { погибших на } 100 \text { тыс. } \\
\text { человек } \\
\end{array}$ & $\begin{array}{c}\text { ОКС в } 2017 \text { г., } \\
\text { на } 100 \text { тыс. } \\
\text { человек }\end{array}$ \\
\hline 1 & Норвегия & 1975 & 2008 & 33 & 2,0 \\
\hline 2 & Швеция & 1977 & 2009 & 32 & 2,5 \\
\hline 3 & Швейцария & 1989 & 2011 & 22 & 2,7 \\
\hline 4 & Великобритания & 1974 & 2009 & 35 & 2,8 \\
\hline 5 & Дания & 1989 & 2011 & 22 & 3,0 \\
\hline 6 & Нидерланды & 1981 & 2009 & 28 & 3,1 \\
\hline 7 & Израиль & 1979 & 2012 & 33 & 3,3 \\
\hline 8 & Эстония & 2003 & 2017 & 14 & 3,6 \\
\hline 9 & Япония & 1975 & 2014 & 39 & 3,7 \\
\hline 10 & Германия & 1987 & 2016 & 29 & 3,8 \\
\hline 11 & Испания & 2002 & 2013 & 11 & 3,9 \\
\hline 12 & Ирландия & 1997 & 2012 & 15 & $3,9(2016)$ \\
\hline 13 & Финляндия & 1990 & 2017 & 27 & 3,9 \\
\hline 14 & Россия & 2017 & 2024 (план) & 7 (план) & 13,0 \\
\hline
\end{tabular}

Источник: Составлено и рассчитано по данным (IRTAD 2018) и полициии.

\section{СТРУКТУРА ДОРОЖНО-ТРАНСПОРТНОЙ СМЕРТНОСТИ В РОССИИ И ЕЕ ДИНАМИКА}

До начала 1980-х годов смертность от ДТП в России устойчиво росла. В период с 1981 по 1983 г. была усилена борьба с нарушениями правил дорожного движения, повышены штрафы. Это в совокупности с антиалкогольной кампанией второй половины 1980-х годов повлияло на снижение смертности от ДТП, но затем она начала расти и достигла 
исторического максимума в 1991 г. К причинам подъема дорожно-транспортной смертности в этот период, в особенности смертности пешеходов, исследователи относят рост легкового автопарка и ослабление надзорной функции полиции (Лунеев 2005). Массовая автомобилизация страны в конце 1990-х - начале 2000-х годов привела к стремительному росту смертности от ДТП водителей и пассажиров в трудоспособных возрастах, что и определило очередной рост общего коэффициента смертности от ДТП, несмотря на позитивные тенденции снижения пешеходной смертности (рисунок 3 ).

По данным полиции, общий коэффициент смертности от ДТП за период с 2014 по 2017 г. существенно снизился (с 19 до 13 погибших на 100 тыс. человек). Подобная интенсивность снижения общего коэффициента дорожно-транспортной смертности не уникальное явление, в некоторых странах оно происходило даже быстрее: в Японии за 2 года, в Нидерландах за 3 года, в Австралии и Португалии за 4 года (IRTAD 2018). К тому же общий коэффициент смертности, равный 19 погибшим на 100 тыс. человек, наблюдался в России и ранее: в 1976, 1983, 1997 и в 2009 г. Соответственно, если взять за точку отсчета любую из этих дат, то период снижения уровня смертности с 19 до 13 погибших на 100 тыс. человек значительно растянется.

Схожесть возрастной структуры населения России и европейского населения 1976 г., принятого за стандарт, проявлялась в равенстве общего и стандартизованного коэффициентов смертности от ДТП в 1980-е и 1990-е годы. Однако с 1998 г. их значения начали расходиться, что объясняется изменениями возрастной структуры населения России.

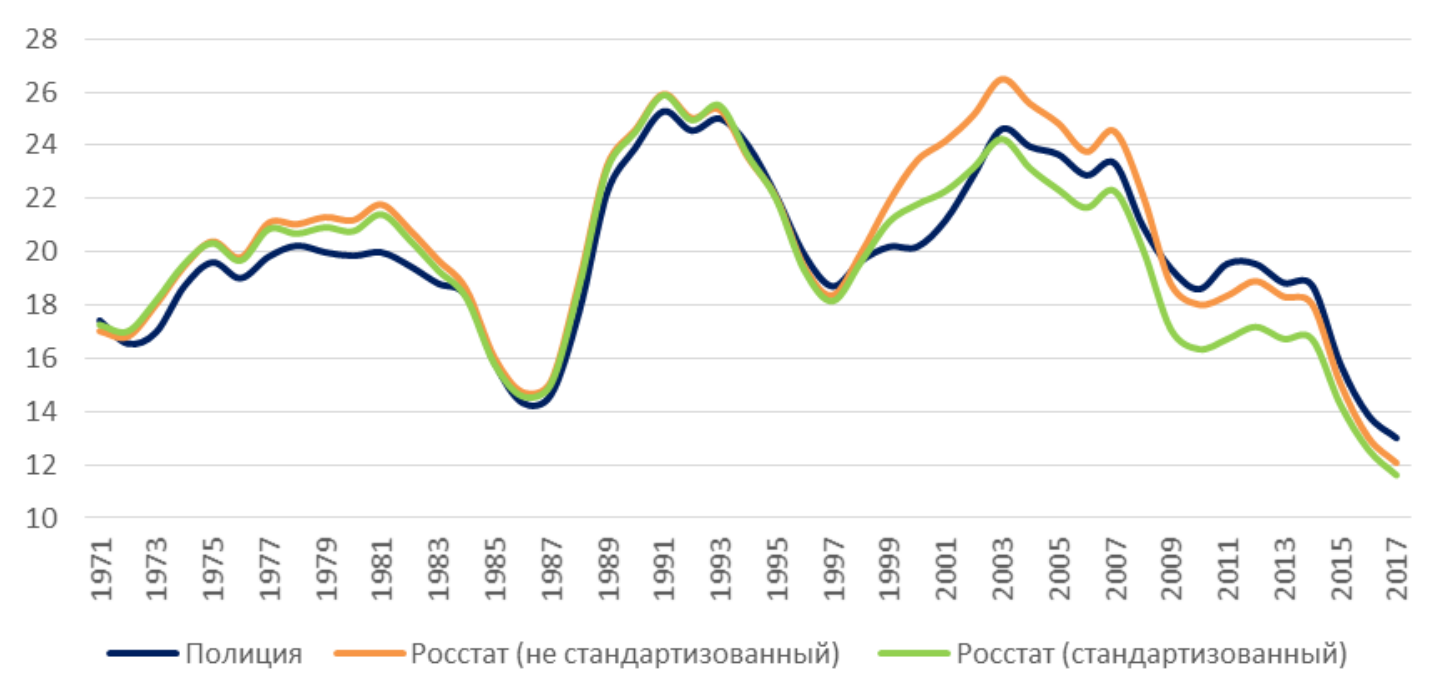

\section{Рисунок 3. Общий коэффициент смертности от ДТП в России по данным полиции и Росстата, на 100 тыс. человек}

\footnotetext{
Примечание: Агрегация причин смерти по группе кодов, относящихся к «мототранспортным дорожным происшествиям (motor vehicle traffic accidents)».
}

Источник: До 1998 г. - данные РосБРиС (Российская экономическая школа 2019), с 1999 г. неопубликованные данные Росстата. 
В стратегии БДД «повышение защищенности от дорожно-транспортных происшествий и их последствий наиболее уязвимых участников дорожного движения, прежде всего детей и пешеходов» является одним из основных направлений реализации стратегии. Действительно, на фоне реализуемых программ по БДД в 2000-е годы шло устойчивое снижение стандартизованного коэффициента смертности пешеходов, но началось оно еще в начале 1990-х годов, до реализации первой ФЦП (рисунок 4). В этот период стандартизованный коэффициент смертности водителей и пассажиров был ниже, чем пешеходов, примерно в 2 раза. С 1998 г. у водителей и пассажиров он начал расти, превысив в 2000 г. уровень смертности пешеходов, и достиг максимальных значений в 2007 г., после чего начал волнообразно снижаться. Первый этап современного снижения смертности водителей и пассажиров пришелся на 2007 - 2011 гг. Он совпал с введением законодательства, регулирующего алкогольную политику в стране, а также ряда законодательных актов, определяющих новый порядок взаимодействия органов ГИБДД с водителями, подозреваемыми в управлении транспортным средством в состоянии алкогольного опьянения (Бурцев и др. 2019). Как было показано ранее, изменения законодательства, регулирующего алкогольную политику, положительно повлияли в этот период на снижение смертности от ДТП мужчин (Pridemore et al. 2013). Второй этап современного снижения смертности водителей и пассажиров начался в 2014 г. и продолжается до сих пор. В этот период было ужесточено законодательство для водителей, управляющих транспортным средством в состоянии алкогольного опьянения, в том числе если это повлекло гибель людей ${ }^{13}$.

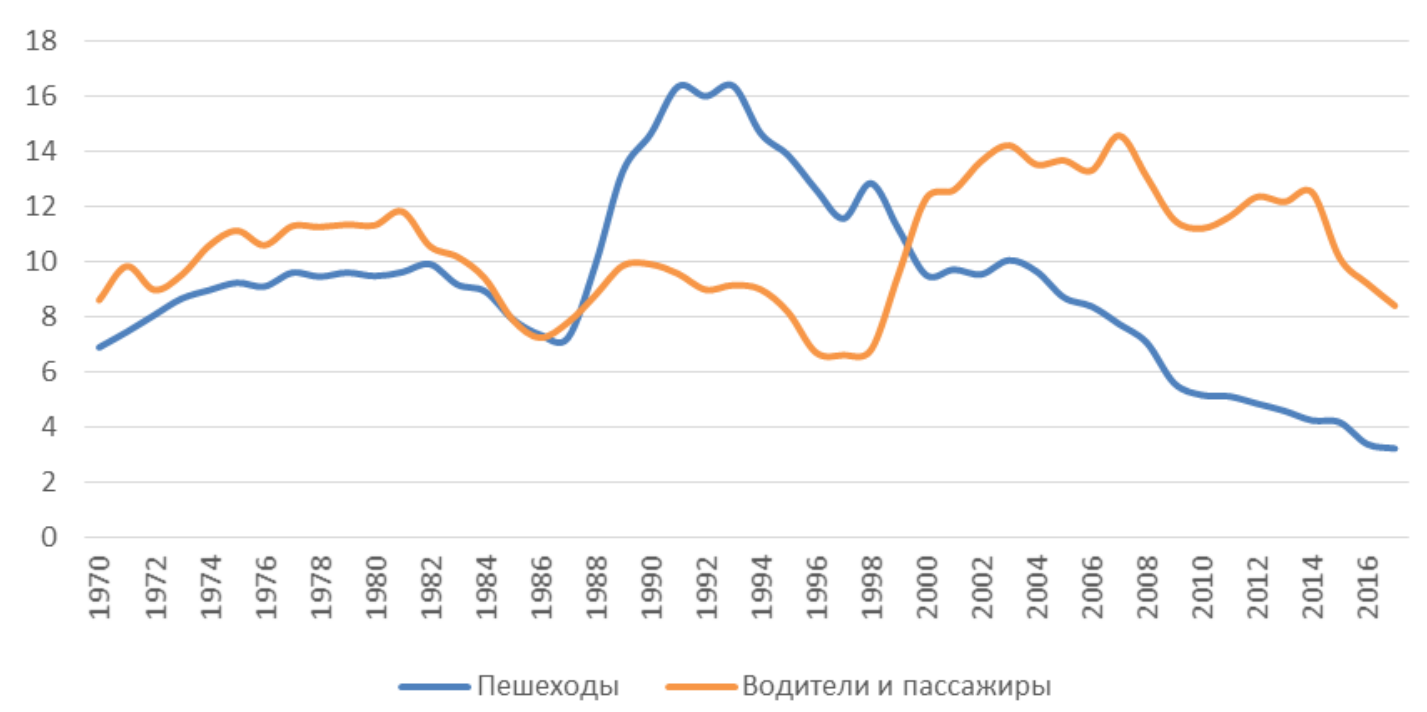

\section{Рисунок 4. Стандартизованный коэффициент смертности от ДТП по категориям} участников дорожного движения, на 100 тыс. человек

Примечание: см. примечание к рисунку 3.

Источник: До 1998 г. - данные РосБРиС (Российская экономическая школа 2019), с 1999 г. неопубликованные данные Росстата.

\footnotetext{
${ }^{13}$ Статья 264.1 УК РФ.
} 
Несмотря на положительные тенденции последних лет и колоссальный прогресс в снижении пешеходной смертности, отставание России от других стран остается значительным. Общий коэффициент смертности российских водителей и пассажиров в 2017 г. (8,9 погибших на 100 тыс. человек) был самым высоким среди стран, представленных на рисунке 5. В странах-соседях, по значению этого показателя, (Польша, Греция, Румыния) он составлял от 5,6 до 6,2 погибших на 100 тыс. человек. Отставание России от этих стран по уровню смертности пешеходов меньше, однако от стран-лидеров (Швеция, Нидерланды) оно десятикратное.

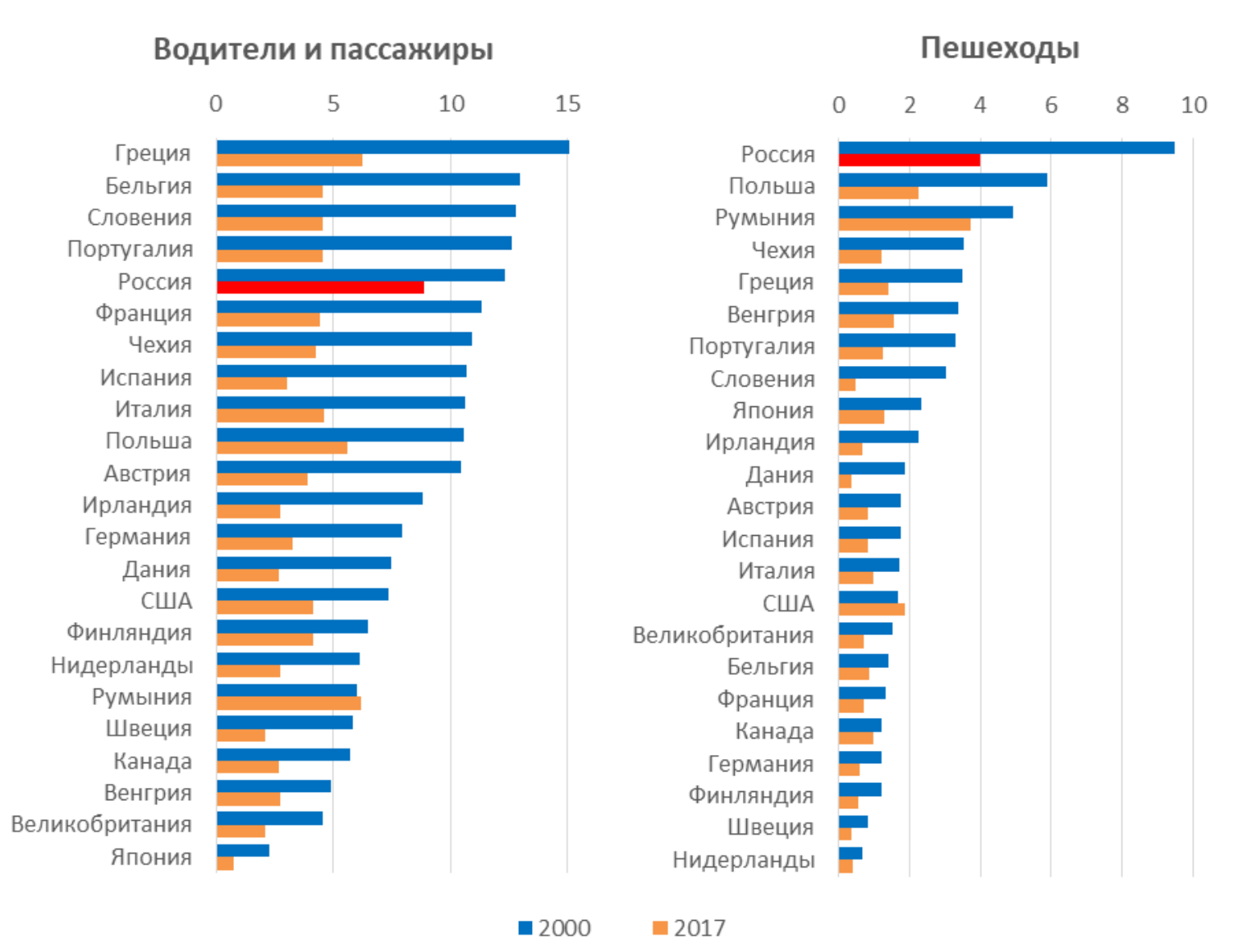

Рисунок 5. Общий коэффициент смертности от ДТП по категориям участников дорожного движения в некоторых странах мира в 2000 и 2017 гг., на 100 тыс. человек

Источник: (IRTAD 2018), данные полиции.

Возрастные коэффициенты смертности пешеходов растут с увеличением возраста, достигая максимума в самых старших возрастах. С наибольшей интенсивностью они растут в возрастах от 0 до 39 лет и после 75 лет, тогда как в возрастной группе 40-74 года они практически стабильны (рисунок 6). Для водителей и пассажиров возрастной профиль смертности кардинально иной: резкий рост, начиная с 15 лет, с достижением пика в 25-29 лет и затем планомерное снижение с увеличением возраста. Поскольку разные категории участников дорожного движения в разных возрастных группах подвержены разным рискам смерти, акценты при формировании политики в области безопасности дорожного движения должны быть расставлены с учетом этих особенностей. 


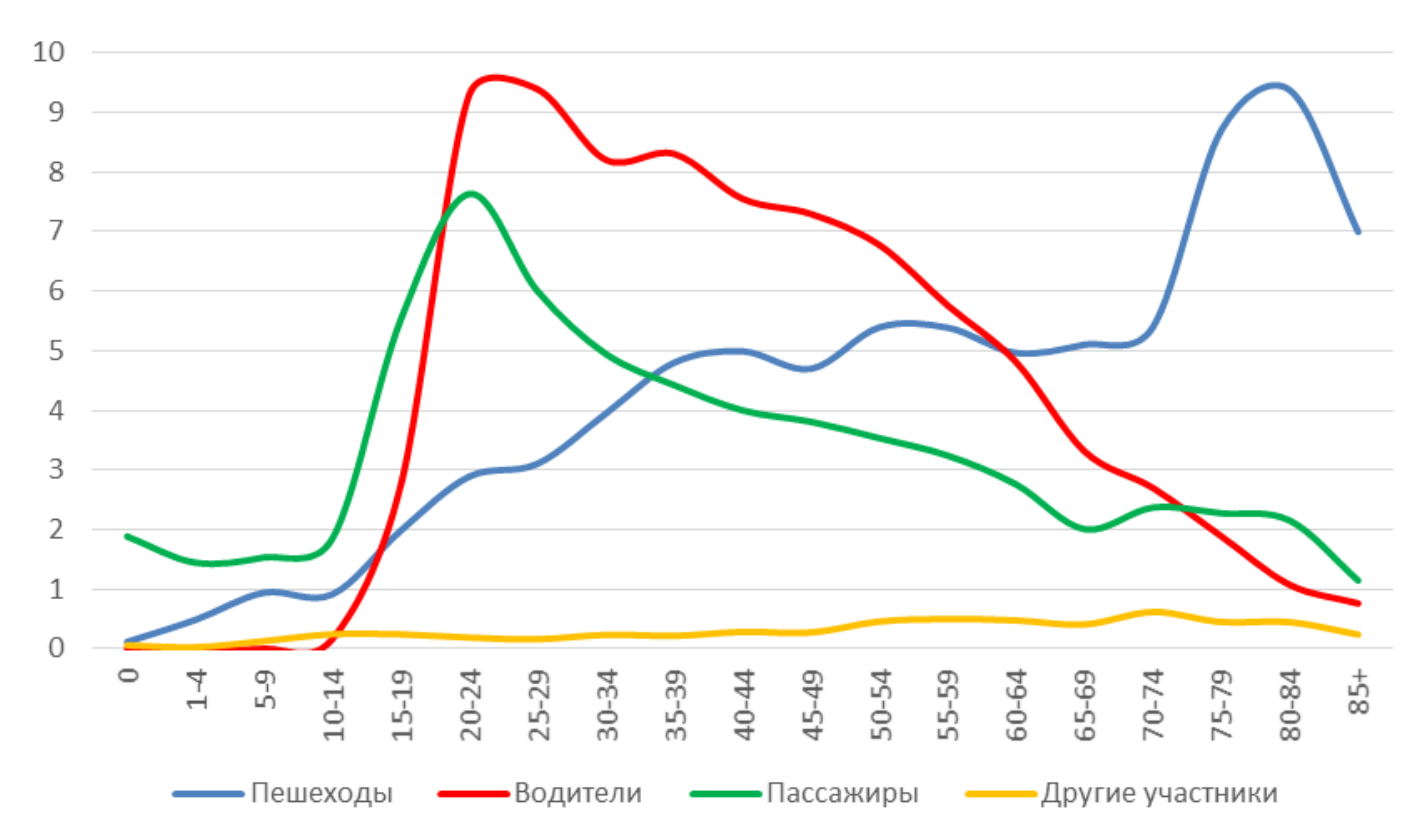

Рисунок 6. Возрастной профиль смертности от ДТП по категориям участников дорожного движения в России, 2017 г., на 100 тыс. человек

Источник: Рассчитано по данным полиции.

Устойчивое снижение стандартизованного коэффициента смертности пешеходов с начала 1990-х годов, о котором говорилось выше, происходило в разных возрастных группах пешеходов с разной интенсивностью (рисунок 7, левая панель). Наиболее интенсивное снижение происходило в самой младшей возрастной группе (0-14 лет), где показатель снизился в 10 раз - с 20 погибших детей на 100 тыс. человек данного возраста в 1991 г. до 2 в 2017 г. С увеличением возраста интенсивность снижения смертности пешеходов снижалась. Так, в возрастных группах 15-29, 30-44, 45-59 и 60+, характеризуемых более высокими показателями смертности, возрастной коэффициент смертности за период 1991-2017 гг. снизился в 7,5; 5,0; 4,0; 3,6 раза соответственно.

Динамика возрастных коэффициентов смертности водителей и пассажиров свидетельствует о менее интенсивном снижении смертности во всех возрастных группах (рисунок 7, правая панель). Положительная динамика не столь ярко выражена по сравнению с пешеходами. Снижение смертности этой категории участников дорожного движения началось в 2007 г., причем одновременно во всех возрастных группах. Наибольшее снижение произошло у детей (0-14 лет) и молодых водителей и пассажиров в возрасте 15-44 года, для которых возрастные коэффициенты смертности за период 2007-2017 гг. снизились в 2 раза. 


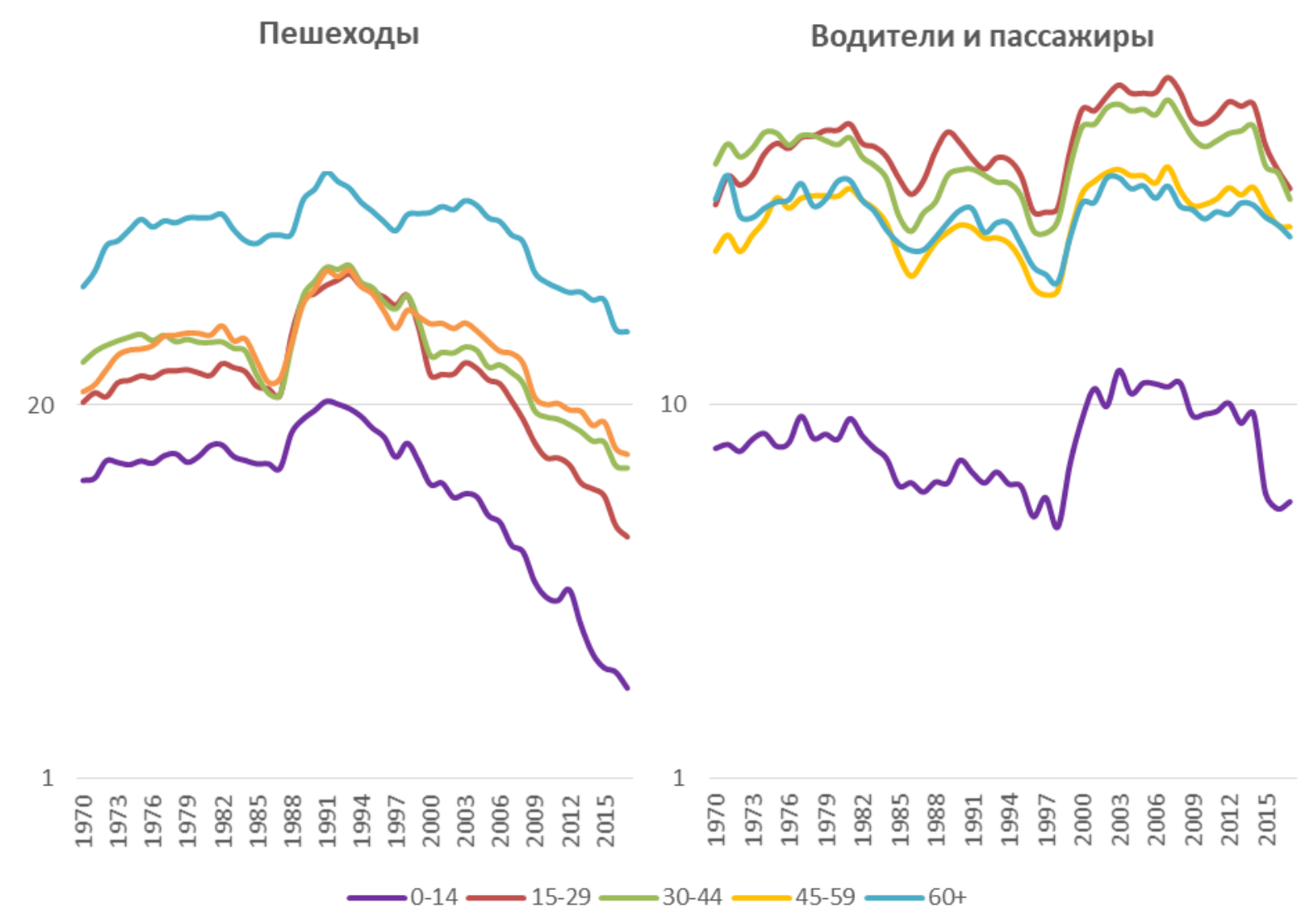

Рисунок 7. Возрастные коэффициенты смертности разных категорий участников дорожного движения в России, на 100 тыс. человек (логарифмическая шкала)

Примечание: Агрегащия причин смерти по группе кодов, относящихся к «мототранспортные дорожные происшествия (motor vehicle traffic accidents)».

Источник: До 1998 г. - данные РосБРиС (Российская экономическая школа 2019), с 1999 г. неопубликованные данные Росстата.

Говоря о детской смертности в ДТП, важно отметить, что ее снижение с 1993 по 2013 г. было обусловлено прежде всего снижением пешеходной детской смертности (рисунок 7, левая панель), тогда как смертность детей-пассажиров не снижалась (рисунок 7, правая панель), несмотря на ужесточение административной ответственности за нарушение правил перевозки детей в автомобиле ${ }^{14}$. В настоящий момент смертность детей-пассажиров в 2,5 раза выше смертности детей-пешеходов, что обусловлено поведением взрослых, поскольку дети-пассажиры до 14 лет являются пассивными участниками дорожного движения. К тому же доля лиц, использующих детские удерживающие устройства при перевозке ребенка в собственном автомобиле, в России остается все еще низкой на фоне других европейских стран - всего около 50\% (WHO 2018a).

\footnotetext{
${ }^{14}$ Кодекс Российской Федерации об административных правонарушениях от 301 декабря 2001 г. №195-Ф3 (ред. от 17.06.2019).
} 


\section{ПРОСТРАНСТВЕННЫЙ АСПЕКТ ДОРОЖНО-ТРАНСПОРТНОЙ СМЕРТНОСТИ в РосСиИ}

В стратегии БДД, к сожалению, отсутствует региональная дифференциация целевых значений дорожно-транспортной смертности. Однако в настоящий момент в России есть регионы, где запланированный уровень дорожно-транспортной смертности уже достигнут (по данным полиции, в Москве и Санкт-Петербурге). Но есть и такие регионы, где снижение общего коэффициента смертности от ДТП до запланированного значения, учитывая его существующий уровень в этих регионах (более 20 погибших в ДТП на 100 тыс. человек), кажется сложновыполнимой задачей. К ним относятся республики Калмыкия, Тыва, Адыгея, Магаданская и Ленинградская области, Забайкальский край.

Интенсивность снижения общего коэффициента смертности в ДТП в регионах не зависела от его уровня в 2003 г., когда начался очередной этап снижения дорожнотранспортной смертности. Если разделить все регионы России по уровню общего коэффициента смертности 2003 г. на три группы (более 25, от 15 до 25, менее 15 погибших на 100 тыс. человек), то окажется, что во всех группах общий коэффициент смертности в ДТП с 2003 по 2018 г. снизился в одинаковой степени: на 43, 45 и 46 п. п. соответственно. Более того, в группе регионов, где этот коэффициент снизился, были такие регионы, как Московская, Тверская, Владимирская области, где общий коэффициент смертности был очень высоким в 2003 г. (более 30 погибших на 100 тыс. человек), так и такие, где он был низким, ниже 13 погибших на 100 тыс. человек (Москва, Санкт-Петербург).

Помимо региональной дифференциации, имеет значение место происшествия: погиб ли человек в населенном пункте или вне него. В период быстрого роста автомобилизации число погибших от ДТП в населенных пунктах превалировало над числом погибших вне них. Однако с 2002 г. это соотношение изменилось и вплоть до 2017 г. число погибших от ДТП в населенных пунктах было ниже числа погибших вне них.

Начиная с 2000 г. доля погибших в населенных пунктах от общего числа погибающих от ДТП постоянно снижалась и достигла в 2014 г. минимального значения $38 \%$, после чего она стабилизировалась и оставалась практически неизменной на протяжении 2015-2018 гг.

Снижение общего коэффициента смертности от ДТП в период с 2003 по 2014 г. происходило преимущественно в населенных пунктах, тогда как аналогичный показатель за их пределами вплоть до 2014 г. не менялся (рисунок 8). С 2014 г. снижение общего коэффициента смертности от ДТП в населенных пунктах замедлилось, тогда как вне них ускорилось.

Отмечается дифференциация дорожно-транспортной смертности и по типам населенных пунктов: городским и сельским. Если в 2015 г. общий коэффициент смертности от ДТП в городских населенных пунктах был выше аналогичного показателя в сельских, то к 2017 г. ситуация стала обратной. В этот период общий коэффициент смертности от ДТП в городских населенных пунктах снижался, тогда как в сельских - рос (таблица 3). Снижение общего коэффициента смертности от ДТП городского населения происходило в городах с численностью населения более 250 тыс. человек, наиболее поступательно - 
в городах-миллионниках. Динамика показателя в городах с численностью населения менее 250 тыс. человек больше похожа на сельскую.

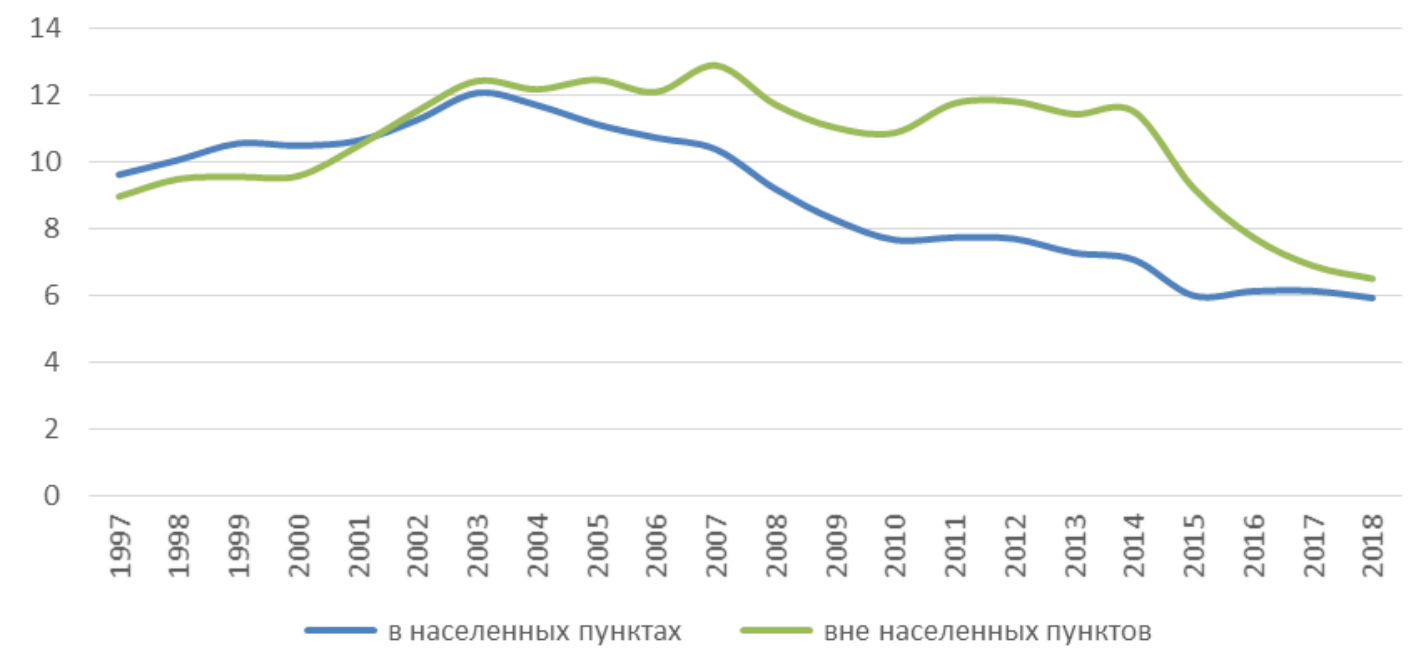

Рисунок 8. Динамика общего коэффициента смертности от ДТП в зависимости от места происшествия, на 100 тыс. всего населения

Источник: Данные полищии.

Таблица 3. Число погибших и общий коэффициент смертности от ДТП в городах с разной численностью населения и сельских населенных пунктах в России

\begin{tabular}{|c|c|c|c|c|c|c|}
\hline & \multicolumn{5}{|c|}{ В городских населенных пунктах } & \multirow{3}{*}{$\begin{array}{c}\text { В сельских поселениях } \\
\text { и сельских населенных } \\
\text { пунктах в городских } \\
\text { поселениях и округах }\end{array}$} \\
\hline & \multirow[b]{2}{*}{ Всего } & \multicolumn{4}{|c|}{ в том числе с численностью населения } & \\
\hline & & $\begin{array}{c}\text { более } \\
1 \text { млн } \\
\text { человек } \\
\end{array}$ & $\begin{array}{l}\text { от } 250 \text { до } 999 \\
\text { тыс. человек }\end{array}$ & $\begin{array}{c}\text { от } 100 \text { до } 249 \\
\text { тыс. человек }\end{array}$ & $\begin{array}{c}\text { менее } 100 \\
\text { тыс. человек }\end{array}$ & \\
\hline \multicolumn{7}{|c|}{ Число погибших, человек } \\
\hline 2015 & 6892 & 2001 & 2018 & 932 & 1941 & 1860 \\
\hline 2016 & 6526 & 1516 & 1799 & 1011 & 2200 & 2438 \\
\hline 2017 & 6458 & 1444 & 1816 & 1028 & 2170 & 2533 \\
\hline \multicolumn{7}{|c|}{ Число погибших на 100 тыс. населения } \\
\hline 2015 & 6,3 & 6,0 & 7,1 & 6,4 & 5,8 & 5,0 \\
\hline 2016 & 6,0 & 4,6 & 6,3 & 7,0 & 6,6 & 6,5 \\
\hline 2017 & 5,9 & 4,4 & 6,4 & 7,1 & 6,5 & 6,8 \\
\hline
\end{tabular}

Источник: Рассчитано по данным полиции о погибших в ДТП и Росстата о численности населения.

Дифференциация коэффициента смертности от ДТП по городам с разной численностью населения показывает, что в основном, чем крупнее города, тем ниже уровень смертности. Это верно как для большинства европейских стран, так и для России в целом (таблица 4).

С одной стороны, в российских городах-миллионниках запланированные целевые показатели снижения смертности к 2024 г., по данным полиции, уже достигнуты в 2017 г. Поэтому приоритетами политики в области безопасности дорожного движения должны стать города с меньшей численностью населения. С другой стороны, общий коэффициент смертности от ДТП в российских городах-миллионниках непозволительно высок по сравнению с аналогичными по численности населения городами Великобритании, 
Германии, Испании, Франции, стран Северной Европы и сопоставим лишь с городамимиллионниками Италии и стран Восточной Европы. Во многих европейских городахмиллионниках (Берлин, Париж, Лондон, Стокгольм и др.) с сопоставимым с российским уровнем автомобилизации (в среднем 329 автомобилей на 1000 населения) общий коэффициент смертности в среднем составляет 1,9 погибших на 100 тыс. населения, тогда как в России аналогичный показатель в 2,3 раза выше.

Таблица 4. Общий коэффициент смертности от ДТП в городах с разной численностью населения в некоторых европейских странах, группах стран и в России, на 100 тыс. населения

\begin{tabular}{|c|c|c|c|c|}
\hline & \multicolumn{4}{|c|}{ Города с населением: } \\
\hline & $\begin{array}{c}\text { более } \\
1 \text { млн } \\
\text { человек }\end{array}$ & $\begin{array}{l}\text { от } 999 \text { до } \\
250 \text { тыс. } \\
\text { человек }\end{array}$ & $\begin{array}{l}\text { от } 249 \text { до } \\
100 \text { тыс. } \\
\text { человек }\end{array}$ & $\begin{array}{l}\text { менее } \\
100 \text { тыс. } \\
\text { человек }\end{array}$ \\
\hline Великобритания (2017) & 1,8 & 1,8 & 1,9 & 2,5 \\
\hline Германия (2016) & 1,6 & 1,9 & 2,4 & 3,0 \\
\hline Испания (2016) & 1,9 & 2,0 & 2,1 & 2,2 \\
\hline Италия (2017) & 3,9 & 3,9 & 5,1 & 5,1 \\
\hline Франция (2015) & 1,9 & 2,5 & 2,9 & 3,5 \\
\hline Швеция (2018), Норвегия (2013), Финляндия (2017) & 0,9 & 1,4 & 1,9 & 2,2 \\
\hline $\begin{array}{l}\text { Болгария (2017), Чехия (2016), Эстония (2017), Латвия } \\
(2017) \text {, Литва (2017), Венгрия (2017), Польша (2014), } \\
\text { Словения (2017), Словакия (2017) }\end{array}$ & 3,2 & 3,4 & 4,8 & 5,5 \\
\hline $\begin{array}{l}\text { Бельгия (2016), Нидерланды (2013), Ирландия (2011), } \\
\text { Швейцария (2016) }\end{array}$ & 1,4 & 2,6 & 2,6 & 1,9 \\
\hline Россия (2017) & 4,4 & 6,4 & 7,1 & 6,5 \\
\hline
\end{tabular}

Источник: Рассчитано по данным (Eurostat 2019), Россия - по данным полиции.

Существенная региональная дифференциация дорожно-транспортной смертности в России, видимо, отчасти обусловливается характером расселения, степенью урбанизации и транспортной связанностью территории региона. Для городов-миллионников цели снижения дорожно-транспортной смертности могли бы быть более амбициозными, поскольку потенциал снижения в них не исчерпан. Исходя из международного опыта и современных российских тенденций, смертность в ДТП в крупных и средних городах России должна составлять 1,5-2 погибших на 100 тыс. человек, в небольших по численности населения городах и сельских населенных пунктах - 2,5-3 погибших на 100 тыс. человек. Лишь при таких показателях смертности в городах и сельских населенных пунктах и при фиксированном сегодняшнем уровне смертности вне населенных пунктов возможно достичь среднего показателя 4 погибших на 100 тыс. человек.

\section{ОГРАНИЧЕНИЯ}

Исследование не было лишено ограничений. В данной работе мы рассматривали российскую смертность от ДТП только в контексте впервые принятой стратегии по безопасности дорожного движения, оставив за рамками изменения законодательства в других сферах, таких как административный и уголовный кодекс, нормативно-правовые акты, регулирующие оборот алкоголя в стране, направления на медицинские освидетельствования, стратегические и программные документы в области 
здравоохранения и др. Фокусировка на стратегии безопасности дорожного движения нам казалась оправданной, поскольку подобный документ задает принципиальное видение проблемы дорожно-транспортной смертности и целевые ориентиры по ее снижению.

При использовании данных полиции в международных сопоставлениях общие коэффициенты смертности не стандартизованы, что обусловлено, прежде всего, ограничением международной базы данных IRTAD, не позволяющей дифференцировать погибших по полу и возрасту.

В работе отсутствует анализ дифференциации погибших в ДТП по полу, поскольку изучение половых различий смертности не входило в задачи данного исследования. Но такая дифференциация в России существует, и она достаточно значима.

При анализе долгосрочных трендов дорожно-транспортной смертности в разрезе категорий участников дорожного движения не выделена категория «велосипедисты», что объясняется сложностью выделения данной категории в государственной статистике смертности и статистике полиции на протяжении всего временного периода. Учитывая небольшое число погибших велосипедистов в России (в 2016 г. 392 человека) на фоне общего числа погибших, мы полагаем, что это незначительно повлияло на динамику смертности незащищенных участников дорожного движения, куда традиционно в международной практике относят не только пешеходов, но и велосипедистов.

Динамика числа погибших и общий коэффициент смертности в ДТП по городам с раной численностью населения и сельским населенным пунктам представлены за короткий период времени (всего 3 года), что объясняется глубиной архива открытого источника информации (статистическая информация на сайте ГИБДД), не содержащего данных за более ранний период.

Помимо этого, все варианты числа погибших на основе государственной статистики смертности даны без учета возможного влияния так называемых «мусорных» кодов причин смерти ${ }^{15}$. Из них к кодам, которые могли бы оказывать влияние на статистику смертности от ДТП, относятся коды такой рубрики МКБ-10, как «повреждения с неопределёнными намерениями» (Y10-Y34). ВО3 взяла на вооружение эту концепцию и включает эти коды в свой короткий список «мусорных» кодов (World health organization 2014: 4). Как было показано на примере исследования по дорожно-транспортной смертности в Москве с использованием связанных данных полиции и государственной статистики смертности, использование «мусорных» кодов все же имеет место и в России при кодировании случаев смерти, которые полиция рассматривает как ДТП (Пьянкова и др. 2019). Если же сделать поправку на эти коды, то число погибших в ДТП на основе государственной статистики смертности увеличится, а расхождения данных полиции и государственной статистики смертности о числе погибших в ДТП может сократиться.

\footnotetext{
15 Понятие «мусорные» коды причин смерти было введено в 1990 г. Нагави и Лопесом в проекте «Глобальное бременя болезней». Под «мусорным» кодом причины смерти понимается такой код, который не может или не должен быть использован в качестве первоначальной причины смерти (Murray CJL, Lopez A.D. 1996). Затем концепция «мусорных» кодов была ими расширена, дана их классификация (Naghavi, Makela, Foreman et al. 2010).
} 


\section{ЗАКЛЮЧЕНИЕ}

Говоря о целевых ориентирах снижения дорожно-транспортной смертности, заложенных в стратегии БДД, рассмотрение ДТП как полностью устранимой причины смерти правомерно и не вызывает сомнений. Однако сроки, установленные в российской стратегии безопасности дорожного движения на 2018-2024 гг. для достижения поставленной цели, очень сжаты, с точки зрения международного опыта и существующего уровня смертности от данной причины. В мировой истории не было прецедентов, когда смертность от ДТП удавалось снизить в 3,5 раза за 7 лет.

В стратегии БДД среди всех категорий участников дорожного движения прежде всего выделены дети и пешеходы, чей уровень смертности в последнее время снижался интенсивней всего, по сравнению с другими категориями участников дорожного движения, тогда как основными группами риска на протяжении долгих лет являются водители и пассажиры в возрасте 15-44 года и пешеходы старше 60 лет. Однако, если среди пешеходов снижение смертности кажется устойчивым трендом без видимых признаков стабилизации, то для водителей и пассажиров говорить об устойчивости снижения смертности можно пока с осторожностью.

Достижение целевых показателей в рамках мониторинга реализации стратегии БДД необходимо рассматривать дифференцированно как по типам регионов в зависимости от существующего уровня, так и по месту происшествия (в или вне населенных пунктов). На сегодняшний день лишь в крупных и средних по численности населения городах есть возможность достичь целей стратегии БДД на 2018-2024 гг.

В выделении контингента лиц, погибших в ДТП, на основе статистики смертности самым первым шагом может быть отказ Росстата от используемого в данный момент подхода на основе действующей краткой номенклатуры причин смерти и переход на один из двух международных вариантов агрегации трехзначных кодов причин смерти, который использует ВОЗ для выделения числа погибших в ДТП. Это приведет к устранению существующих значительных расхождений между опубликованными числами погибших в двух официальных системах учета погибших от ДТП в России, однако не устранит их полностью. Наибольшее приближение к понятию погибшего в ДТП в рамках системы учета полиции дает выборка трехзначных кодов причин смерти, используемая ВОЗ в рамках проекта «Глобальное бремя болезней» и обозначаемая как погибшие в «дорожных происшествиях» (Road injury). В условиях отнесения судебно-медицинскими экспертами в России существенного числа смертей от ДТП к недорожным или неуточненным как дорожным или недорожным случаям нецелесообразно использовать выборку четырехзначных кодов, также предлагаемую ВОЗ, поскольку это в очередной раз приведет к занижению числа погибших в «дорожных происшествиях». В этом случае на легко устранимую проблему перехода на международный подход агрегации кодов причин смерти накладывается более сложная проблема точного определения обстоятельств происшествия судебно-медицинскими экспертами в условиях полностью децентрализованной системы кодирования причин смерти в России и отсутствия двусторонней эффективно работающей связи с представителями полиции. 
Одновременно в рамках системы учета погибших в полиции целесообразно вести отдельный учет происшествий, не соответствующих понятию ДТП из «Глоссария по статистике транспорта», и впоследствии не включать их в официальное число погибших в ДТП до данным полиции.

Усиление межведомственного взаимодействия, например, между полицией и системой государственной регистрации смертей, может выразиться в создании возможности либо предварительного кодирования сотрудниками полиции обстоятельств транспортного происшествия на языке МКБ-10 на этапе заполнения карточки учета ДТП, либо возможности корректирования обстоятельств ДТП на этапе взаимодействия с судебно-медицинскими экспертами. С ними же необходимо наладить систему двустороннего информационного взаимодействия как с целью повышения качества кодирования данной причины смерти в медицинском свидетельстве о смерти и снижения числа случаев смерти в результате происшествий неуточненных как дорожное или недорожное, так и с целью исключения случаев смерти от естественных причин смерти в системе учета полиции.

Однако у научного сообщества все же остаются определенные опасения, связанные с возможным изменением качества регистрации смертей от ДТП и их последствий в статистике естественного движения населения в ближайшие годы. Так, например, произошло с болезнями системы кровообращения после объявления Президентом 2015 г. годом борьбы с сердечно-сосудистыми заболеваниями (Вишневский, Андреев, Тимонин 2016).

\section{ЛИТЕРАТУРА}

Баканов К.С. (2019, май). Совершенствование системы учета погибших в дорожнотранспортных происшествиях. Доклад, представленный на встрече рабочей группы по мониторингу ключевых показателей безопасности дорожного движения в Российской Федерации Европейского регионального бюро ВОЗ, РФ, Москва, представительство ООН в РФ.

Бурцев А.А., Киржанова В.В., Григорова Н.И., Баканов К.С. (2019). Основные тренды показателей медицинского освидетельствования на состояние опьянения в Российской Федерации в 2004-2017 гг. Наркология, 18(4), 3-17. doi: 10.25557/1682-8313.2019.04.3-17

Вишневский А.Г., Андреев Е.М., Тимонин С.А. (2016). Смертность от болезней системы кровообращения и продолжительность жизни в России. Демографическое обозрение, 3(1), 6-34. doi:10.17323/demreview.v3i1.1761

Данилова И.А. (2015). Особенности построения непрерывных рядов показателей смертности по причинам смерти в России. Вопросы статистики, 11, 58-68. doi: $10.34023 / 2313-6383-2015-0-11-58-68$

Европейская экономическая комиссия ООН (2009). Глоссарий по статистике транспорта. URL:

https://www.unece.org/fileadmin/DAM/trans/main/wp6/pdfdocs/glossen4.pdf (13.09.2019) 
Лунеев В.В. (2005). Преступность ХХ века: мировые, региональные и российские тенденщии. Москва: Волтет Клувер.

Милле Ф., Школьников В.М., Эртриш В., Валлен Ж. (1996). Современные тенденции смертности по причинам смерти в России 1965-1994. Москва-Париж.

URL: http://www.demoscope.ru/weekly/knigi/shkol/shkol.html (13.09.2019)

Пьянкова А.И., Фаттахов Т.А., Баканов К.С., Юрасова Е.Д. (2019). Смертность от дорожно-транспортных происшествий в Москве: анализ связанных данных полиции и государственного статистического учета умерших. Демографическое обозрение, 6(1), 151-176. doi: 10.17323/demreview.v6i1.9115

Российская экономическая школа (2019). Российская база данных по рождаемости и смертности. Россия, по причинам смерти, пятилетние возрастные группы, 19591988 гг; Россия и регионы, по причинам смерти, пятилетние возрастные группы, 19891998 гг. URL: http://demogr.nes.ru/index.php/ru/demogr_indicat/data (данные загружены 22.04.2019).

Федеральная служба государственной статистики (2017). Демографический ежегодник России 2017. Статистический сборник. Москва: Росстат.

Danilova I., Shkolnikov V.M., Jdanov D.A., Meslé F., Vallin J. (2016) Identifying potential differences in cause-of-death coding practices across Russian regions. Population health metrics, 14(8), 1-20. doi:10.1186/s12963-016-0078-0

European Commission (2017). Annual accident report 2017. European Commission, Directorate General for Transport. URL:

https://ec.europa.eu/transport/road_safety/sites/roadsafety/files/pdf/statistics/dacota/asr2017. pdf (13.09.2019)

Eurostat (2019). Regions and cities; People killed in road accidents (per 10000 population) 2017. Available at https://ec.europa.eu/eurostat/cache/RCI/\#?vis=city.statistics\&lang=en (22.04.2019)

IRTAD (2018). Road safety annual report 2018. International traffic safety data and analysis group. URL: https://www.itf-oecd.org/sites/default/files/docs/irtad-road-safety-annual-report2018_2.pdf (13.09.2019)

Murray CJL, Lopez A.D. (eds.). (1996). The Global Burden of Disease and Injury 1: A comprehensive assessment of mortality and disability from diseases, injuries, and risk factors in 1990 and projected to 2020. London, UK: Harvard University Press on behalf of the World Health Organization and World Bank.

Naghavi M., Makela S., Foreman K. et al. (2010). Algorithms for enhancing public health utility of national causes-of-death data. Population health metrics, 8(1), 9. doi: 10.1186/1478-7954-8-9

Pridemore W., Chamlin M. B., Kaylen M. T., Andreev E. (2013). The impact of a national alcohol policy on deaths due to transport accidents in Russia. Addiction, 108, 2112-2118. doi:10.1111/add.12311

UN Road Safety Collaboration (2010). White paper for safe roads in 2050. Achieving Zero Work-Related Road Deaths. URL: https://www.who.int/roadsafety/events/unrsc_12_appendix_11.pdf (13.09.2019)

World health organization (WHO) (2014). WHO methods and data sources for country-level causes of death 2000-2012. Geneva: WHO. URL: 
https://www.who.int/healthinfo/global_burden_disease/GlobalCOD_method_2000_2012.pdf (13.09.2019)

World health organization (WHO) (2018b). WHO methods and data sources for country-level causes of death 2000-2016. Geneva. URL:

http://terrance.who.int/mediacentre/data/ghe/GlobalCOD_method_2000_2016.pdf?ua=1 (13.09.2019)

World health organization (WHO) (2018a). Global status report on road safety 2018. Geneva.

\section{ПРИЛОЖЕНИЕ}

Таблица П1. Транспортные происшествия в кратком листе причин смерти МКБ-9 и советских кратких номенклатурах причин смерти, действовавших в период МКБ-9

\begin{tabular}{|c|c|c|}
\hline $\begin{array}{l}\text { Номер } \\
\text { рубрики }\end{array}$ & Русское название & Английское название \\
\hline \multicolumn{3}{|c|}{ Краткий лист причин смерти МКБ-9 } \\
\hline E471 & $\begin{array}{l}\text { Происшествия с участием автомобильного } \\
\text { транспорта }\end{array}$ & Motor vehicle traffic accidents \\
\hline E472 & $\begin{array}{l}\text { Происшествия с другими с дорожными } \\
\text { транспортными средствами }\end{array}$ & Other road vehicle accidents \\
\hline $\mathrm{E} 470$ & Железнодорожные происшествия & Railway accidents \\
\hline E473 & Аварии на водном транспорте & Water transport accidents \\
\hline E474 & Авиационные и космические аварии & Air and space transport accidents \\
\hline 160 & $\begin{array}{l}\text { кая краткая номенклатура причин смерти } 1981 \text { г., } \\
\text { Несчастные случаи, связанные с мототранспортом, } \\
\text { исключая случаи на производстве }\end{array}$ & $\begin{array}{l}\text { твующая с } 1981 \text { по } 1987 \text {. } \\
\text { Motor vehicle traffic accident, } \\
\text { excluding occupational }\end{array}$ \\
\hline 161 & $\begin{array}{l}\text { Автомототранспортный несчастный случай на } \\
\text { общественной дороге в результате наезда на } \\
\text { пешехода }\end{array}$ & $\begin{array}{l}\text { Motor vehicle traffic accident } \\
\text { involving collision with pedestrian }\end{array}$ \\
\hline 162 & $\begin{array}{l}\text { Несчастные случаи, связанные с мототранспортом, } \\
\text { случаи на производстве }\end{array}$ & $\begin{array}{l}\text { Motor vehicle traffic accident, } \\
\text { occupational }\end{array}$ \\
\hline 163 & $\begin{array}{l}\text { Автомототранспортные несчастные случаи, } \\
\text { исключая случаи на производстве }\end{array}$ & $\begin{array}{l}\text { Accidents involving other types of } \\
\text { transport, excluding occupational }\end{array}$ \\
\hline 164 & $\begin{array}{l}\text { Автомототранспортные несчастные случаи, случаи } \\
\text { на производстве }\end{array}$ & $\begin{array}{l}\text { Accidents involving other types of } \\
\text { transport, occupational }\end{array}$ \\
\hline \multicolumn{3}{|c|}{ Советская краткая номенклатура причин смерти 1988 г., действующая с 1988 по 1998 г. } \\
\hline 160 & Несчастные случаи, связанные с мототранспортом & Motor vehicle traffic accident \\
\hline 161 & $\begin{array}{l}\text { Автомототранспортный несчастный случай на } \\
\text { общественной дороге в результате наезда на } \\
\text { пешехода }\end{array}$ & $\begin{array}{l}\text { Motor vehicle traffic accident } \\
\text { involving collision with pedestrian }\end{array}$ \\
\hline 162 & Автомототранспортные несчастные случаи & Other transport accidents \\
\hline
\end{tabular}




\section{Таблица П2. Транспортные происшествия в российских кратких номенклатурах причин смерти, действовавших в период МКБ-10}

\begin{tabular}{|c|c|c|}
\hline $\begin{array}{l}\text { Номер } \\
\text { рубрики }\end{array}$ & Русское название & Английское название \\
\hline \multicolumn{3}{|c|}{ Краткая номенклатура причин смерти, действовавщая в период 1999-2005 г2. } \\
\hline 239 & $\begin{array}{l}\text { Пешеход, пострадавший в результате транспортного } \\
\text { несчастного случая }\end{array}$ & $\begin{array}{l}\text { Pedestrian injured in transport } \\
\text { accident }\end{array}$ \\
\hline 240 & $\begin{array}{l}\text { Лицо, находившееся в легковом автомобиле, пострадавшее } \\
\text { в результате транспортного несчастного случая }\end{array}$ & $\begin{array}{l}\text { Car occupant injured in transport } \\
\text { accident }\end{array}$ \\
\hline 241 & Другие и неуточненные транспортные несчастные случаи & $\begin{array}{l}\text { Other and unspecified transport } \\
\text { accidents }\end{array}$ \\
\hline \multicolumn{3}{|c|}{ Краткая номенклатура причин смерти, действовавшая в период 2006-2010 г2. } \\
\hline 239 & $\begin{array}{l}\text { Пешеход, пострадавший в результате транспортного } \\
\text { несчастного случая }\end{array}$ & $\begin{array}{l}\text { Pedestrian injured in transport } \\
\text { accident }\end{array}$ \\
\hline 272 & $\begin{array}{l}\text { Пешеход, пострадавший от внедорожного } \\
\text { мототранспортного несчастного случая }\end{array}$ & $\begin{array}{l}\text { Pedestrian injured in collision with } \\
\text { motor vehicle, non-traffic accident }\end{array}$ \\
\hline 240 & $\begin{array}{l}\text { Лицо, находившееся в легковом автомобиле, пострадавшее } \\
\text { в результате транспортного несчастного случая }\end{array}$ & $\begin{array}{l}\text { Car occupant injured in transport } \\
\text { accident }\end{array}$ \\
\hline 241 & Другие и неуточненные транспортные несчастные случаи & $\begin{array}{l}\text { Occupant of other transport vehicle } \\
\text { in transport accident }\end{array}$ \\
\hline 273 & $\begin{array}{l}\text { Другое лицо, пострадавшее от внедорожного } \\
\text { мототранспортного несчастного случая }\end{array}$ & $\begin{array}{l}\text { Other persons injured in collision } \\
\text { with motor vehicle, non-traffic } \\
\text { accident }\end{array}$ \\
\hline 274 & Другие транспортные несчастные случаи & Other transport accidents \\
\hline \multicolumn{3}{|c|}{ Краткая номенклатура причин смерти, действующая с 2011 г. } \\
\hline 256 & $\begin{array}{l}\text { Пешеход, пострадавший в результате дорожного } \\
\text { транспортного случая }\end{array}$ & $\begin{array}{l}\text { Pedestrian injured in road traffic } \\
\text { cases (except rail) }\end{array}$ \\
\hline 259 & $\begin{array}{l}\text { Пешеход, пострадавший в результате недорожного } \\
\text { транспортного случая (кроме железнодорожного) }\end{array}$ & $\begin{array}{l}\text { Pedestrian injured in road mobile } \\
\text { case (except rail) }\end{array}$ \\
\hline 263 & $\begin{array}{l}\text { Пешеход, пострадавший в результате неуточненного } \\
\text { транспортного случая (кроме железнодорожного) }\end{array}$ & $\begin{array}{l}\text { Pedestrian injured in unspecified } \\
\text { transport case (except rail) }\end{array}$ \\
\hline 257 & $\begin{array}{l}\text { Велосипедист (любой), мотоциклист (любой) и лицо, } \\
\text { находящееся в трехколесном транспортном средстве, } \\
\text { пострадавшие в результате дорожного транспортного } \\
\text { случая }\end{array}$ & $\begin{array}{l}\text { Cyclist (any), the motorcyclist } \\
\text { (any) and a person in a } \\
\text { threewheeled vehicle, injured in } \\
\text { road traffic cases }\end{array}$ \\
\hline 260 & $\begin{array}{l}\text { Велосипедист (любой), мотоциклист (любой) и лицо, } \\
\text { находящееся в трехколесном транспортном средстве, } \\
\text { пострадавшие в результате недорожного транспортного } \\
\text { случая }\end{array}$ & $\begin{array}{l}\text { Cyclist (any), the motorcyclist } \\
\text { (any) and a person in a } \\
\text { threewheeled vehicle, injured } n \\
\text { road mobile case }\end{array}$ \\
\hline 258 & $\begin{array}{l}\text { Лицо, находившееся в автотранспортном средстве, } \\
\text { пострадавшее в результате дорожного транспортного } \\
\text { случая }\end{array}$ & $\begin{array}{l}\text { The person that was found in the } \\
\text { vehicle injured in road traffic cases }\end{array}$ \\
\hline 261 & $\begin{array}{l}\text { Лицо, находившееся в автотранспортном средстве, } \\
\text { пострадавшее в результате недорожного транспортного } \\
\text { случая }\end{array}$ & $\begin{array}{l}\text { The person that was found in the } \\
\text { vehicle affected by the-road case }\end{array}$ \\
\hline 262 & $\begin{array}{l}\text { Пешеход, пострадавший при столкновении с поездом или } \\
\text { другим железнодорожным транспортным средством }\end{array}$ & $\begin{array}{l}\text { Pedestrian injured in a collision } \\
\text { with a train or other railway vehicle }\end{array}$ \\
\hline 268 & Другие и неуточненные транспортные несчастные случаи & $\begin{array}{l}\text { Other and unspecified transport } \\
\text { accidents }\end{array}$ \\
\hline 264 & $\begin{array}{l}\text { Погружение в воду и утопление в результате аварии на } \\
\text { водном транспортном средстве }\end{array}$ & $\begin{array}{l}\text { Immersion in water and drowning } \\
\text { in an accident on the water craft }\end{array}$ \\
\hline 265 & $\begin{array}{l}\text { Погружение в воду и утопление, связанное с водным } \\
\text { транспортом, не связанное с аварией на нем }\end{array}$ & $\begin{array}{l}\text { Immersion in water and drowning } \\
\text { related to water transport is not } \\
\text { associated with an accident on it }\end{array}$ \\
\hline 266 & $\begin{array}{l}\text { Другие и неуточненные несчастные случаи на водном } \\
\text { транспорте }\end{array}$ & $\begin{array}{l}\text { Other and unspecified accidents in } \\
\text { water transport }\end{array}$ \\
\hline 267 & $\begin{array}{l}\text { Несчастные случаи на воздушном транспорте и при } \\
\text { космических полетах }\end{array}$ & $\begin{array}{l}\text { Accidents in air transport and space } \\
\text { travel }\end{array}$ \\
\hline
\end{tabular}




\title{
ROAD TRAFFIC MORTALITY IN RUSSIA:
}

\section{ASSESSMENT APROACHES, TRENDS AND PERSPECTIVES}

\author{
ANASTASIYA PYANKOVA, TIMUR FATTAKHOV
}

\begin{abstract}
In 2016, the crude death rate from road traffic accidents in Russia decreased, according to police data, to a level not observed since 1971, after which it continued to decline. The positive trends apparently served as the basis for the optimistic goals laid down in the road safety strategy for 2018-2024.

Based on police data, state statistics on mortality and international databases on mortality and road safety, the authors try to answer these questions: Are the goals set achievable within the specified timeframe, and how consistent are they with European trends in road traffic mortality, as well as with Russia's current differentiation of road traffic mortality by space, age and category of road users?

The study showed that the deadlines for achieving targets in the road safety strategy are very tight. Today, only large and medium-sized cities have the potential to implement a new road safety strategy in which the crude death rate should not exceed 1.5-2 deaths per 100 thousand people by 2024, whereas in small cities and rural settlements - 2.5-3 deaths per 100 thousand people. For many years, the main risk groups have been drivers and passengers aged 15-44 and pedestrians over 60, who do not appear in the road safety strategy as priority categories.

In addition, the article shows that in order to eliminate the existing discrepancies between the numbers of deaths published by the two official accounting systems (the police and Rosstat), the very first step might be for Rosstat to stop calculating the road traffic death toll based on the current brief list of causes of death and transition to one of the two international options for aggregating three-digit codes of causes of death used by the WHO.
\end{abstract}

Key words: road traffic accidents, road safety, road traffic mortality, police data, vital statistics.

Anastasiya Pyankova (apyankova@hse.ru), National Research University Higher School of Economics, Russia.

Timur Fattakhov (tfattahov@hse.ru), National Research University Higher School of Economics, Russia.

THE STUDY WAS IMPLEMENTED UNDER THE GRANT FROM RUSSIAN FOUNDATION FOR BASIC RESEARCH № 19-013-00060 «ROAD-TRAFFIC MORTALITY IN RUSSIA AND ITS REGIONS: ANALYSIS BASED ON LINKED POLICE ROAD-CRASH RECORDS WITH MORTALITY STATISTICS (DEATH CERTIFICATES)».

DATE RECEIVED : JULY 2019.

\section{REFERENCES}

Bakanov K.S. (2019, May). Improvement of statistics on fatalities in road accidents. Report presented at the meeting of the working group on monitoring key road safety indicators in the Russian Federation, WHO Regional office for Europe, Russia, Moscow. (In Russ.).

Burtsev A.A., Kirzhanova V.V., Grigorova N.I., Bakanov K.S. (2019). Main trends of medical examination indicators on the state of drinking in the Russian Federation in 2004-2017. Narcology, 18(4), 3-17. doi: 10.25557/1682-8313.2019.04.3-17 (In Russ.).

Danilova I., Shkolnikov V.M., Jdanov D.A., Meslé F., Vallin J. (2016) Identifying potential differences in cause-of-death coding practices across Russian regions. Population health metrics, 14(8), 1-20. doi:10.1186/s12963-016-0078-0 
Danilova I.A. (2015). Specific features of the reconstruction of continuous cause-specific mortality time-series for Russia. Voprosy statistiki, 11, 58-68. doi: 10.34023/2313-63832015-0-11-58-68 (In Russ.).

European Commission (2017). Annual accident report 2017. European Commission, Directorate General for Transport. URL:

https://ec.europa.eu/transport/road_safety/sites/roadsafety/files/pdf/statistics/dacota/asr2017. pdf (13.09.2019)

Eurostat (2019). Regions and cities; People killed in road accidents (per 10000 population) 2017. Available at https://ec.europa.eu/eurostat/cache/RCI/\#?vis=city.statistics\&lang=en (22.04.2019)

Federal State Statistics Service (2017). The Demographic Yearbook of Russia 2017. Statistical handbook. Moscow: Rosstat.

IRTAD (2018). Road safety annual report 2018. International traffic safety data and analysis group. URL: https://www.itf-oecd.org/sites/default/files/docs/irtad-road-safety-annual-report2018_2.pdf (13.09.2019)

Luneev V.V. (2005) Prestupnost XX veka: mirovye, regionalnye i rossijskie tendencii. Moscow: Voltet Kluver.

Meslé F., Shkolnikov V., Hertrich V., Vallin, J. (1996). Recent trends in mortality by causes of death in Russia during 1965-1994. Paris-Moscow. URL:

http://www.demoscope.ru/weekly/knigi/shkol/shkol.html (In Russ.) (13.09.2019)

Murray CJL, Lopez A.D. (eds.). (1996). The Global Burden of Disease and Injury 1: A comprehensive assessment of mortality and disability from diseases, injuries, and risk factors in 1990 and projected to 2020. London, UK: Harvard University Press on behalf of the World Health Organization and World Bank.

Naghavi M., Makela S., Foreman K. et al. (2010). Algorithms for enhancing public health utility of national causes-of-death data. Population health metrics, 8(1), 9.

doi: $10.1186 / 1478-7954-8-9$

New economic school (2019). Russian Fertility and Mortality Database. Russia, causes of death, 5-year age groups, 1959-1988; Russia and regions, causes of death, 5-year age groups, 1989-1998 . Available at http://demogr.nes.ru/index.php/ru/demogr_indicat/data (22.04.2019).

Pridemore W., Chamlin M. B., Kaylen M. T., Andreev E. (2013). The impact of a national alcohol policy on deaths due to transport accidents in Russia. Addiction, 108, 2112-2118. doi:10.1111/add.12311

Pyankova A.I, Fattakhov T.A., Bakanov K., Yurasova E.D. (2019). Road traffic mortality in Moscow: record linkage study using police data and vital statistics. Demographic review, 6(1), 151-176. doi: 10.17323/demreview.v6i1.9115. (In Russ.)

UN Road Safety Collaboration (2010). White paper for safe roads in 2050. Achieving Zero Work-Related Road Deaths. URL: https://www.who.int/roadsafety/events/unrsc_12_appendix_11.pdf (13.09.2019)

UNECE UN (2009). The Glossary for Transport Statistics. Retrieved from https://www.unece.org/fileadmin/DAM/trans/main/wp6/pdfdocs/glossen4.pdf (13.09.2019)

Vishnevsky A.G., Andreev E.M., Timonin S.A. (2016). Mortality from cardiovascular diseases and life expectancy in Russia. Demographic review, 3(1), 6-34. doi:10.17323/demreview.v3i1.1761. (In Russ.). 
World health organization (WHO) (2014). WHO methods and data sources for country-level causes of death 2000-2012. Geneva: WHO. URL:

https://www.who.int/healthinfo/global_burden_disease/GlobalCOD_method_2000_2012.pdf (13.09.2019)

World health organization (WHO) (2018b). WHO methods and data sources for country-level causes of death 2000-2016. Geneva. URL:

http://terrance.who.int/mediacentre/data/ghe/GlobalCOD_method_2000_2016.pdf?ua=1 (13.09.2019)

World health organization (WHO) (2018a). Global status report on road safety 2018. Geneva. 